\title{
PENGEMBANGAN PRAKTIKUM KIMIA ORGANIK 1 MENGGUNAKAN APLIKASI ADOBE FLASH
}

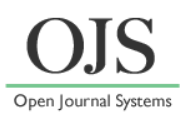

\author{
Dewi Handayani $^{1 *}$ dan Agus Sundaryono ${ }^{2}$ \\ ${ }^{1}$ Program Studi Pendidikan Kimia FKIP, Universitas Bengkulu. Jl. WR Supratman, Bengkulu \\ ${ }^{2}$ Program Studi S2 Pendidikan IPA FKIP, Universitas Bengkulu. Jl. WR Supratman, Bengkulu \\ *E-mail: d.handayani@unib.ac.id
}

DOI: https://doi.org/10.33369/pendipa.4.2.58-65

\begin{abstract}
The purposes of this research are to develop the practicum of organic chemistry 1 by using the Adobe Flash application and to describe the student's feasibility and response to the practicum developed. This development research adapted from the development model according to Sugiyono.. The participant in this research is $3 \mathrm{rd}$ semester students of Chemistry Education Study Program in the academic year of 2018/2019. The data of this study were obtained from the results of interviews, questionnaire validation of material and media experts, readability questionnaires and student responses to product usage tests. Based on the results of research that has been done, several stages of development ranging from problem identification, data collection, product design, design validation, design revision, and product trials have been carried out. The results of the validation of material experts obtained an average of 4,20 (valid category) and an average media expert of 4.275 (valid category). For the readability test of the developed guide, it was obtained 4.204 (very interesting category and student response was 3,936 (interesting category). The organic chemistry lab guide 1 using the Adobe Flash program has a nice and attractive appearance and design because students can directly access the practical lab guide using a smartphone I laptop, as well as directly filling out observations and discussions on the laptop. Inside there are also videos and materials that are presented virtually that motivate students to do practical work. Based on the results of expert validation and testing to students, the development of the organic chemistry 1 practicum guide was feasible to be applied in learning activities in class.
\end{abstract}

Keywords: Organic Chemistry 1 Practicum, Adobe Flash, Research and Development

\begin{abstract}
ABSTRAK
Tujuan dari penelitian ini adalah untuk mengembangkan praktikum kimia organik 1 dengan menggunakan aplikasi adobe flash serta mendeskripsikan kelayakan dan respon mahasiswa terhadap praktikum yang dikembangkan. Penelitian ini merupakan penelitian pengembangan yang diadaptasi dari model pengembangan menurut Sugiyono. Partisipan dalam penelitian adalah mahasiswa semester 3 Program Studi Pendidikan Kimia Tahun akademik 2018/ 2019. Data penelitian ini diperoleh dari hasil wawancara, angket validasi ahli materi dan media, angket keterbacaan dan respon mahasiswa pada uji pemakaian produk. Berdasarkan hasil penelitian yang telah dilakukan, beberapa tahap pengembangan mulai dari identifikasi masalah, pengumpulan data, desain produk, validasi desain, revisi desain, dan uji coba produk telah dilakukan. Hasil validasi ahli materi diperoleh rata rata sebesar 4,20 (kategori valid) dan ahli media rata rata sebesar 4,275(kategori valid). Untuk uji coba keterbacaan penuntun yang dikembangakan diperoleh sebesar 4,204 (kategori sangat menarik dan respon mahasiswa sebesar 3,936 (menarik). Penuntun praktikum kimia organik 1 menggunakan program Adobe Flash memiliki tampilan dan desain yang bagus dan menarik karena mahasiswa bisa langsung mengakses penuntun praktikum menggunakan smartphone/ laptop, serta langsung mengisi hasil pengamatan dan pembahasan di laptop. Di dalamnya juga terdapat video serta materi yang disajikan secara virtual sehingga memotivasi mahasiswa untuk melakukan praktikum. Berdasarkan hasil validasi ahli dan uji coba ke mahasiswa, pengembangan penuntun praktikum kimia organik 1 ini layak untuk diterapkan dalam kegiatan pembelajaran di kelas.
\end{abstract}

Kata Kunci: Praktikum Kimia Organik 1, Adobe Flash, Penelitian dan pengembangan (Research and Development) 


\section{PENDAHULUAN}

Kimia Organik merupakan salah satu mata kuliah wajib yang harus diambil oleh mahasiswa Program Studi (Prodi) Pendidikan Kimia Universitas Bengkulu yang terdiri dari 4 SKS. 3 SKS teori dan 1 SKS praktikum. Saat ini penuntun praktikum yang ada baru versi cetak dan belum ada pengembangan dalam bentuk digital. Oleh karena itu, untuk mendapatkan hasil yang lebih baik maka perlu dikembangkan penuntun praktikum digital menggunakan aplikasi adobe flash.

Kegiatan praktikum dapat melatih siswa/ mahasiswa menjadi pemikir ilmiah dan memiliki pemahaman yang mendalam terhadap konsep ilmiah utama. Pemikiran ilmiah yang baik berarti mampu menghasilkan pertanyaan untuk penyelidikan, pengembangan hipotesis yang masuk akal, merancang eksperimen terkendali, mengumpulkan dan mempresentasikan data yang tepat, menggunakan bukti untuk mendukung simpulan dan secara efektif menyampaikan proses eksperimen (Stone, R., 2013).

Kegiatan praktikum Kimia Organik 1 selama ini telah dilakukan, menurut mahasiswa penuntun praktikum Kimia Organik 1 tidak kontekstual, kurang menarik, dan kurang aplikatif. Oleh karena itu, untuk menambah motivasi dan semangat mahasiswa untuk mengikuti praktikum dibuatlah penuntun praktikum dengan menggunakan aplikasi adobe flash. Dalam penerapannya, Adobe Flash dapat digunakan untuk membuat media pembelajaran interaktif secara efektif dan efisien serta mudah diakses oleh mahasiswa, sebab dunia pendidikan dituntut untuk selalu berkembang secara cepat mengikuti perkembangan ilmu dan teknologi. Dengan menggunakan software Adobe Flash dapat dibuat media pembelajaran berbasis multimedia. Kemampuan program Adobe Flash dalam membuat presentasi multimedia mendukung pembuatan animasi secara langsung dengan penyisipan sound dan gambar. Adobe Flash merupakan software yang simpel dan mudah dalam pengoperasian. Kelebihan kemudahan pengoperasian dalam penggunaan media pembelajaran berbasis Adobe Flash yaitu dengan penggunan fungsi tombol-tombol interaktif yang memudahkan kegiatan belajar mengajar sesuai yang diinginkan (Merdekawati dan Agustin, 2014). Pemilihan Adobe Flash untuk membuat media dapat meningkatkan pemahaman mahasiswa karena Adobe Flash mampu menciptakan media pembelajaran interaktif yang menyediakan fasilitas suara, gambar, animasi dan lain sebagainya.

Dalam menghadapi era industri 4.0, dosen harus kreatif dalam menumbuhkan semangat belajar mahasiswa termasuk dalam melakukan praktikum. Kecendrungan karakteristik mahasiswa generasi $\mathrm{Z}$ diantaranya adalah (1). Mahir dan termotivasi dalam menggunakan teknologi digital. Pembelajaran perlu melibatkan penggunaan teknologi digital, untuk menggali pengetahuan, berdiskusi secara virtual, presentasi dalam diskusi kelas bahkan dalam melakukan kegiatan praktikum di laboratorium. (2). Terpapar secara intensif oleh gagasan dan produk-produk inovatif \& kreatif. Pembelajaran perlu menstimulasi peserta didik terlibat dalam proses kreatif untuk mengivovasi dan memecahkan masalah.

Berkaitan dengan era industri 4.0, mahasiswa saat ini lebih cenderung memanfaatkan infrastruktur ICT dan perangkat pembelajaran virtual untuk memberikan fleksibilitas bagi peserta didik untuk menemukan sumber-sumber belajar yang berkualitas, merekam data, menganalisis data, dan menyusun laporan dan melakukan presentasi. Peserta didik di abad 21 saat ini cenderung menggunakan sosial media/ elektronik dalam pembelajarannya. (Handayani, D., dkk. 2018)

Dengan menggunakan penuntun praktikum ini, mahasiswa dapat langsung mengerjakan pre test, membaca materi praktikum, prosedur praktikum, membuat laporan praktikum secara langsung, serta dapat mengerjakan post test. Hasil laporan praktikum, nilai pre test dan post test masing-masing individu dapat di print dan dijadikan satu dalam bentuk laporan akhir. Penuntun praktikum ini juga bersifat offline, jadi tidak perlu akses internet/ WIFI. Mahasiswa cukup membawa laptop atau smartphone yang bisa dimasukkan penuntun praktikum digitalnya (asalkan di perangkat smartphone mahasiswa sudah tersedia aplikasi adobe flash). Pembuatan penuntun praktikum digital ini juga cukup mudah dan sederhana. Dalam penelitian ini topik praktikum yang akan dikembangkan adalah pada topik pelarut organik. Kegiatan praktikum dalam proses pembelajaran sejalan dengan peralihan 
paradigma pembelajaran dari behavioristik menjadi konstruktivistik yang menuntut mahasiswa untuk dapat memperoleh pengetahuannya secara mandiri. Dengan praktikum, mahasiswa dapat memperoleh pengetahuan dan pengalaman secara langsung, dapat mengembangkan keterampilan serta dapat berperan aktif dalam kegiatan pengamatan atau eksperimen.

Penelitian ini menjadi penting, karena dapat menghasilkan produk penuntun praktikum berbasis digital pada mata kuliah Kimia Organik 1. Hasil yang diharapkan tersedianya referensi yang lengkap untuk mata kuliah ini, bukan hanya buku ajar akan tetapi juga penuntun praktikumnya sehingga bisa digunakan oleh dosen dan mahasiswa yang membutuhkan.

\section{METODE PENELITIAN}

Jenis penelitian yang digunakan dalam
penelitian ini adalah penelitian dan pengembangan (Research and Development). Penelitian dan pengembangan merupakan proses atau metode yang digunakan untuk validasi dan mengembangkan produk (Sugiyono, 2017). Metode penelitian dan pengembangan adalah metode yang digunakan untuk menghasilkan produk tertentu dan menguji keefektifan produk tersebut. Untuk dapat menghasilkan produk tertentu digunakan penelitian yang bersifat analisis kebutuhan dan untuk menguji keefektifan produk tersebut supaya dapat berfungsi di masyakat luas, maka diperlukan penelitian untuk menguji keefektifan produk tersebut (Sugiyono, 2012).

Dalam penelitian ini yang menjadi populasi adalah seluruh mahasiswa semester III Program Studi Pendidikan Kimia Tahun akademik 2018/ 2019. Sampel dalam penelitian ini (uji coba kelas kecil) adalah 9 orang mahasiswa semester III Program Studi Pendidikan Kimia.

Langkah-langkah penelitian dan pengembangan (R\&D) menurut Sugiono ada 10 langkah. Dalam penelitian ini ini hanya terdiri dari tujuh langkah, yaitu : 1) potensi dan masalah, 2) mengumpulkan data, 3) desain produk, 4) validasi desain, 5) revisi desain, 6) uji coba produawal/ kelas kecil, 7) revisi produk. Instrumen pada penelitian ini berupa angket validasi perangkat praktikum dan angket tanggapan mahasiswa terhadap e-modul praktikum. Teknik analisis data terdiri atas uji normalitas, uji validasi tim ahli, analisis keterbacaan modul praktikum, dan analisis angket respon mahasiswa terhadap e-modul praktikum.

\section{HASIL DAN PEMBAHASAN}

Hasil pengembangan pada penelitian ini berupa penuntun praktikum kimia organik 1 menggunakan program Adobe Flash pada materi pelarut organik. Penelitian dan pengembangan ini dilaksanakan di Laboratorium Pembelajaran Kimia FKIP Universitas Bengkulu untuk mengetahui kelayakan dan respon mahasiswa terhadap Penuntun Praktikum Kimia organik 1 menggunakan program Adobe Flash. Dalam penelitian ini menggunakan model yang diadaptasi dari model pengembangan menurut Sugiyono. Tahap pengembangan yang dilakukan oleh peneliti yaitu: 1) identifikasi masalah; 2) pengumpulan data; 3) desain produk; 4) validasi desain; 5) revisi desain; 6) uji coba produk; 7) revisi produk. Berikut hasil penelitian yang dilakukan sebagai berikut :

\section{Identifikasi Masalah}

Saat ini penutun praktikum yang ada masih berupa buku penuntun biasa, belum digital. Dengan berkembangnya teknologi saat ini, mahasiswa sangat memerlukan suatu inovasi dalam pengembahangan bahan ajar/ penuntun praktikum yang berbasis teknologi. Oleh sebab itu perlu dikembangkan Penuntun Praktikum Kimia Organik 1 menggunakan program Adobe Flash.

\section{Mengumpulkan Data}

Setelah proses tahap identifikasi potensi dan masalah selesai, maka tahap kedua yaitu mencari informasi berupa sumber yang menunjang penyusunan bahan ajar. Peneliti dalam hal ini mengumpulkan data dengan melakukan wawancara dengan tim dosen pengampu kimia organik serta melakukan observasi ke laboratorium pembelajaran untuk melihat kondisi laboratorium serta kondisi alat dan bahan yang tersedia. Berdasarkan hasil observasi juga diketahui bahwa keadaan laboratorium dikategorikan baik serta alat dan bahan yang dimiliki juga masih keadaan bagus. Akan tetapi, selama ini dalam praktikum masih menggunakan modul praktikum biasa belum menggunakan penuntun praktikum digital. Oleh karena itu 
dalam penelitian, dicobakan menggunakan penuntun praktikum menggunakan program Adobe Flash.

\section{Desain Produk}

Penuntun praktikum kimia organik 1 ini dapat dioperasikan menggunakan smartphone android dan laptop/komputer dengan format program swf dan exe; ukuran huruf disesuaikan pada setiap frame agar mudah terbaca; jenis huruf Arial, Cambria dan Malgun Gothic.

Adobe Flash CS3 merupakan program utama dalam pembuatan penuntun praktikum kimia ini dan juga didukung oleh beberapa program. Penuntun praktikum yang dikembangkan terdiri dari bagian pendahuluan, bagian menu, bagian isi dan bagian penutup.

a) Bagian pendahuluan

Bagian pendahuluan terdapat judul penuntun, kata pengantar, tata cara penggunaan, tata tertib laboratorium, daftar alat yang digunakan berserta fungsinya dan bagian form pengisian nama dan kelompok mahasiswa.

b) Bagian menu

Dibagian menu ini terdapat menu cek pemahaman awal, menu kompetensi, menu praktikum, menu evaluasi dan menu profil peneliti.

c) Bagian isi

Dibagian isi ini terdapat tujuan percobaan, bagian engagement, bagian exploration, bagian explanation, bagian elaboration.

d) Bagian penutup

Tampilan dari menu ini terdiri dari menu print untuk menyatakan ingin mencetak semua data yang telah di isi atau menyimpan data dalam bentuk pdf.

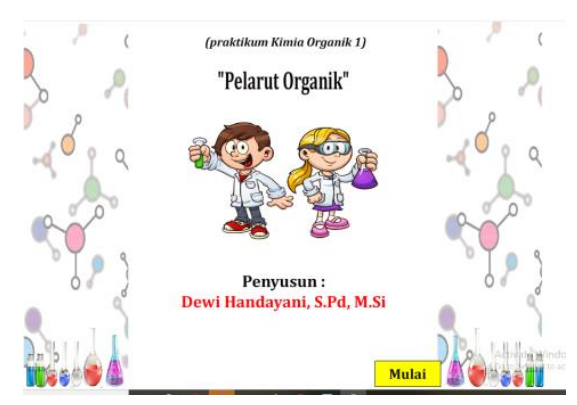

Gambar 1. Tampilan depan
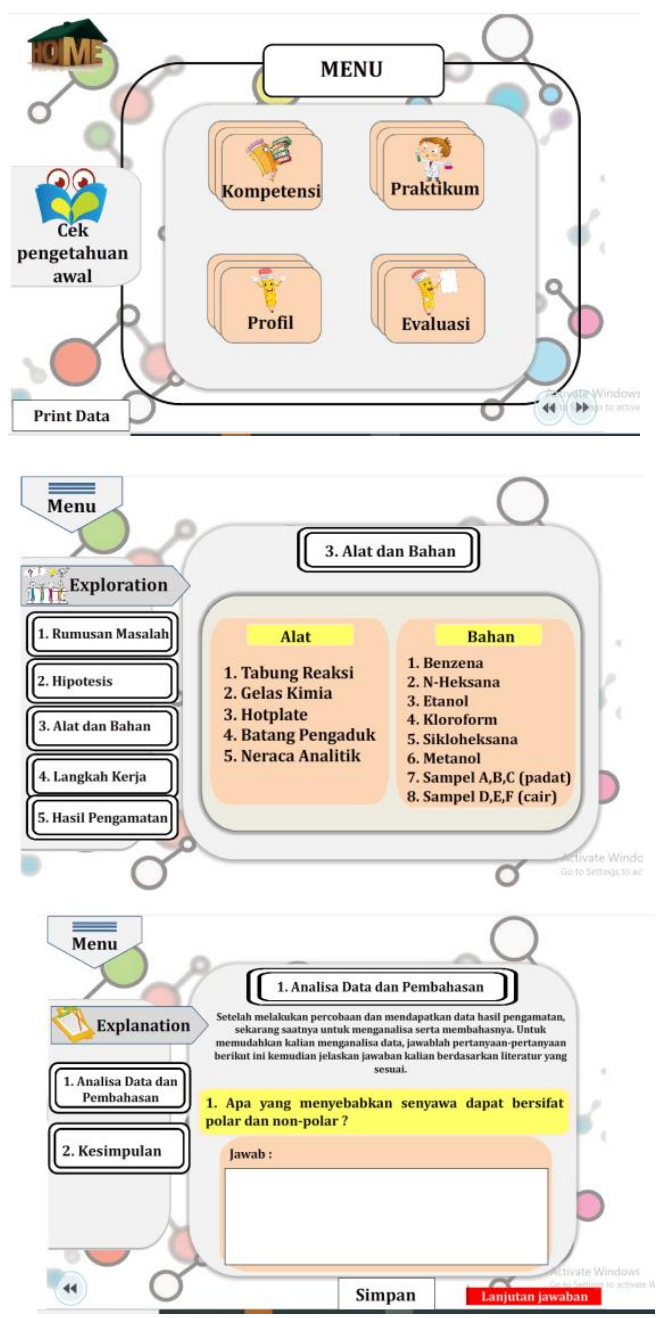

Gambar 2. Tampilan isi

Buku petunjuk praktikum disusun dalam sebuah buku yang digunakan untuk menunjang ketercapaian suatu pembelajaran (Arifah, Isnaeni, 2014). Buku penuntun praktikum juga digunakan sebagai instruksi atau informasi yang disajikan dalam bentuk tulisan dengan maksud agar peserta didik (praktikan) dapat bekerja mandiri (individual atau berkelompok) dalam melangsungkan prosedur percobaan (eksperimen) untuk mencapai tujuan percobaan (Guntari, Desi Destiani. 2012).

Pembuatan penuntun praktikum ini berfungsi untuk melatih kemampuan berpikir kritis mahasiswa. Seseorang yang berpikir kritis akan mengevaluasi dan kemudian menyimpulkan suatu hal berdasarkan fakta untuk membuat yang keputusan sehingga penggunaan buku penuntun praktikum berdampak positif untuk siswa (Tawil, M dan Liliasari, 2014). Sebelum diterapkan di 
kelas, penuntun praktikum ini perlu dilakukan validasi ahli terlebih dahulu. Validasi produk melalui beberapa tahap yaitu validasi materi dan validasi media, dengan memilih validator yang berkompeten secara akademik maupun professional dibidangnya. Penuntun praktikum kimia organik 1 menggunakan program Adobe Flash dinilai kualitasnya oleh dua orang ahli materi yaitu 1 orang dosen Pendidikan Kimia dan 1 orang dosen S2 Pendidikan IPA Universitas Bengkulu serta dua orang ahli media yaitu 1 orang dosen S2 Teknologi Ilmu Pendidikan, Universitas Bengkulu dan 1 orang dari PTP LPMP.

Tabel 1. Hasil Validasi Oleh Ahli Materi

\begin{tabular}{|c|c|c|c|c|}
\hline \multirow[t]{2}{*}{ Aspek } & \multirow{2}{*}{$\begin{array}{l}\text { Pernya } \\
\text { taan }\end{array}$} & \multicolumn{2}{|c|}{ Skor } & \multirow{2}{*}{$\bar{V}$} \\
\hline & & $V_{1}$ & $V_{2}$ & \\
\hline \multirow{8}{*}{$\begin{array}{c}\text { Aspek } \\
\text { Pembelajaran }\end{array}$} & P1 & 4 & 4 & 4 \\
\hline & $\mathrm{P} 2$ & 4 & 4 & 4 \\
\hline & P3 & 4 & 4 & 4 \\
\hline & $\mathrm{P} 4$ & 4 & 4 & 4 \\
\hline & P5 & 4 & 4 & 4 \\
\hline & P6 & 4 & 4 & 4 \\
\hline & P7 & 5 & 5 & 5 \\
\hline & P8 & 4 & 4 & 4 \\
\hline \multirow{12}{*}{$\begin{array}{c}\text { Aspek } \\
\text { Kebenaran } \\
\text { Isi } \\
\end{array}$} & P9 & 5 & 5 & 5 \\
\hline & $\mathrm{P} 10$ & 4 & 4 & 4 \\
\hline & P11 & 5 & 4 & 4,5 \\
\hline & $\mathrm{P} 12$ & 4 & 4 & 4 \\
\hline & $\mathrm{P} 13$ & 4 & 4 & 4 \\
\hline & P14 & 4 & 4 & 4 \\
\hline & P15 & 5 & 4 & 4,5 \\
\hline & P16 & 5 & 5 & 5 \\
\hline & P17 & 4 & 4 & 4 \\
\hline & P18 & 4 & 4 & 4 \\
\hline & P19 & 4 & 4 & 4 \\
\hline & $\mathrm{P} 20$ & 4 & 4 & 4 \\
\hline \multirow{4}{*}{\multicolumn{2}{|c|}{$\begin{array}{c}\text { Total } \\
\text { Rata-rata } \\
\text { Kriteria }\end{array}$}} & 85 & 83 & 84 \\
\hline & & 4,25 & 4,15 & 4,2 \\
\hline & & Sangat & Valid & Sangat \\
\hline & & Valid & & Valid \\
\hline
\end{tabular}

Tabel 2. Hasil Validasi Oleh Ahli Media

\begin{tabular}{|c|c|c|c|c|}
\hline \multirow[t]{2}{*}{ Aspek } & \multirow{2}{*}{$\begin{array}{l}\text { Pernya } \\
\text { taan }\end{array}$} & \multicolumn{2}{|c|}{ Skor } & \multirow{2}{*}{$\bar{V}$} \\
\hline & & $\mathbf{V}_{1}$ & $\mathbf{V}_{2}$ & \\
\hline Aspek & $\mathrm{P} 1$ & 4 & 4 & 4 \\
\hline \multirow[t]{9}{*}{ Tampilan } & $\mathrm{P} 2$ & 4 & 4 & 4 \\
\hline & P3 & 5 & 4 & 4,5 \\
\hline & $\mathrm{P} 4$ & 4 & 4 & 4 \\
\hline & P5 & 4 & 4 & 4 \\
\hline & P6 & 4 & 4 & 4 \\
\hline & $\mathrm{P} 7$ & 4 & 4 & 4 \\
\hline & $\mathrm{P} 8$ & 5 & 5 & 5 \\
\hline & P9 & 4 & 4 & 4 \\
\hline & $\mathrm{P} 10$ & 4 & 4 & 4 \\
\hline Aspek & $\mathrm{P} 11$ & 5 & 4 & 4,5 \\
\hline \multirow[t]{9}{*}{ Pemprograman } & $\mathrm{P} 12$ & 4 & 4 & 4 \\
\hline & $\mathrm{P} 13$ & 4 & 4 & 4 \\
\hline & $\mathrm{P} 14$ & 4 & 4 & 4 \\
\hline & $\mathrm{P} 15$ & 4 & 4 & 4 \\
\hline & $\mathrm{P} 16$ & 5 & 5 & 5 \\
\hline & $\mathrm{P} 17$ & 4 & 5 & 4,5 \\
\hline & $\mathrm{P} 18$ & 5 & 5 & 5 \\
\hline & P19 & 4 & 4 & 4 \\
\hline & $\mathrm{P} 20$ & 5 & 5 & 5 \\
\hline \multicolumn{2}{|l|}{ Total } & 86 & 85 & 85,5 \\
\hline \multirow{3}{*}{\multicolumn{2}{|c|}{$\begin{array}{c}\text { Rata-rata } \\
\text { Kriteria }\end{array}$}} & 4,3 & 4,25 & 4,275 \\
\hline & & Sangat & Sangat & Sangat \\
\hline & & Valid & Valid & Valid \\
\hline
\end{tabular}
dinyatakan valid maka penuntun diuji coba produk dimana pada uji coba produk ini dilakukan sebelum masuk ke tahap uji coba pemakaian. Pada uji coba produk ini, penuntun praktikum kimia organik 1 yang telah dikembangkan diimplementasikan pada 10 mahasiswa Semester 3 Tahun Akademik 2019/ 2020. Pada pelaksanaan praktikum ini, dilaksanakan dengan satu kali pertemuan. Sebelum dilakukan praktikum, mahasiswa diperkenalkan terlebih dahulu penuntun praktikum kimia organik 1 menggunakan program Adobe Flash yang telah dikembangkan. Penuntun praktikum kimia organik 1 digunakan sebagai panduan untuk melaksanakan praktikum pada materi Pelarut Organik. Setelah praktikum selesai, mahasiswa diberi angket lembar keterbacaan. Melihat data hasil validitas dan data hasil uji keterbacaan di atas maka diketahui bahwa penuntun praktikum kimia organik 1 menggunakan program Adobe Flash yang 
dikembangkan peneliti layak untuk diterapkan pada proses pembelajaran.

Mahasiswa diminta untuk mengisi angket keterbacaan terhadap penuntun praktikum kimia organik 1 Menggunakan program Adobe Flash yang sudah digunakan dimana angket keterbacaan ini bertujuan untuk mengetahui keterbacaan dan kemenarikan buku petunjuk praktikum yang dikembangkan. Data hasil uji coba keterbacaan dapat dilihat pada Tabel 3.

Tabel 3. Hasil Uji Coba Keterbacaan

\begin{tabular}{clc}
\hline Aspek & Pernyataan & $\bar{V}$ \\
\hline Aspek Ketepatan & P1 & 4,217 \\
Konsep dengan & P2 & 4,304 \\
Kompetensi & P3 & 4,000 \\
& P4 & 4,000 \\
& P5 & 4,435 \\
\hline & P6 & 4,087 \\
Aspek Kualitas & P7 & 4,261 \\
Tampilan & P8 & 4,217 \\
& P9 & 4,304 \\
& P10 & 4,217 \\
\hline Rata-rata & 4,204 \\
Kriteria : & Sangat \\
& & menarik
\end{tabular}

Berdasarkan data pada tabel 3 hasil uji coba keterbacaan menunjukkan bahwa penuntun praktikum kimia organik 1 yang dikembangkan sangat menarik diketahui dari rata-rata yang didapatkan sebesar 4,204 yang berada pada rentang nilai $4,2 \leq \bar{V}<5$ yang termasuk dalam klasifikasi "sangat menarik". Komentar yang diberikan oleh mahasiswa juga menunjukkan bahwa penuntun praktikum kimia organik 1 menggunakan program Adobe Flash yang dikembangkan sangat menarik dan mudah digunakan. Mahasiswa menyarankan untuk praktikum pada mata kuliah lain juga menerapkan pola yang sama, sehingga lebih praktis dan cepat dalam membuat laporannya.

Sebelum melakukan praktikum peneliti menerangkan petunjuk penggunaan dan menjelaskan isi materi yang terdapat didalam penuntun praktikum kimia organik 1 menggunakan Adobe Flash. Selama proses praktikum mahasiswa sangat antusias dalam mengikuti praktikum yang dilaksanakan oleh peneliti. Ketika proses praktikum berlangsung, mahasiswa juga berperan aktif dalam melakukan setiap percobaan. Setelah praktikum selesai, mahasiswa dimintai tanggapan terhadap penuntun praktikum kimia organik 1 menggunakan program Adobe Flash yang sudah digunakan. Siswa memberikan tanggapan atau respon berupa angket yang dibagikan setelah pelaksanaan praktikum. Hasil angket respon mahasiswa terhadap penuntun praktikum kimia organik 1 menggunakan program Adobe Flash dapat dilihat pada Tabel 4.

Tabel 4. Hasil Angket Respon Mahasiswa

\begin{tabular}{clc}
\hline Aspek & Pernyataan & $\bar{V}$ \\
\hline Aspek & P1 & 3,74 \\
Kemudahan & P2 & 4,04 \\
Pemahaman & P3 & 3,57 \\
& P4 & 3,78 \\
& P5 & 3,65 \\
& P6 & 3,70 \\
& P7 & 4,39 \\
& P8 & 3,83 \\
\hline Aspek & P9 & 3,96 \\
Kemandirian & P10 & 4,26 \\
Belajar & P11 & 3,57 \\
& P12 & 3,91 \\
\hline Aspek & P13 & 4,04 \\
Penyajian & P14 & 4,13 \\
Media & P15 & 4,48 \\
\hline Rata-rata & 3,936 \\
Kriteria & Menarik \\
\hline
\end{tabular}

Berdasarkan data pada tabel 4 hasil angket respon mahasiswa menunjukkan bahwa menarik terhadap penuntun praktikum kimia yang dikembangkan diketahui dari rata-rata yang didapatkan sebesar 3,936 yang berada pada rentang nilai $4,2 \leq \bar{V}<5$ yang termasuk dalam klasifikasi "menarik". Komentar yang diberikan sebagian besar mahasiswa menunjukkan bahwa penuntun praktikum kimia organik 1 menggunakan program Adobe Flash memiliki tampilan dan desain yang bagus dan menarik sehingga memotivasi mahasiswa untuk melakukan praktikum. Aplikasi Flash banyak digunakan dalam pembuatan animasi website, film kartun maupun media pembelajaan interaktif karena memiliki berbagai kelebihan (Wihardjo, Edi, 2007). Oleh karena itu penerapan aplikasi ini pada penuntun praktikum sangat baik jika dikembangkan lebih lanjut sehingga mahasiswa 
menjadi lebih bersemangat dalam melakukan praktikum. Hasil penelitian sebelumnya dalam penerapan aplikasi adobe flash ini menunjukkan bahwa multimedia yang dikembangkan layak digunakan guru sebagai bahan ajar di kelas dan dpat dijadikan sebagai sumber belajar dalam kegiatan pembelajaran indivual siswa karena memiliki kualitas yang baik (Ditama, Viandhika, 2015). Dengan adanya penggunaan media pembelajaran yang menarik dan beragam akan semakin meningkatkan mutu pembelajaran (Alperi,,M dan Handayani. D., 2018).

Penyusunan buku penuntun praktikum dimaksudkan untuk memperlancar dan memberikan suatu informasi atau materi pembelajaran sebagai acuan bagi peserta didik dalam melaksanakan kegiatan praktikum. Buku petunjuk praktikum berfungsi sebagai bahan ajar yang dapat meminimalkan peran dari seorang pendidik. Selain itu, adanya buku petunjuk praktikum memacu keaktifan peserta didik dalam memperoleh pengetahuan yang bermakna dan menjadikan untuk berpikir kreatif dan terampil sains. Hal ini dapat memudahkan pendidik dalam melaksanakan pengajaran di dalam laboratorium (Septiana, Nurul, 2016). Saat ini belum banyak yang mengembangkan penuntun praktikum dalam bentuk digital. Pada penelitian yang telah dilakukan, kegiatan praktikum menjadi lebih praktis, paperless, lebih menarik dan bisa dibawa kemana-mana karena bisa dibaca melalui media handphone. Mahasiswa bisa belajar mandiri dan bisa melihat animasi pendukung dalam materi praktikum. Hal ini sejalan dengan penelitian Alperi, M (2019) yang menyatakan bahwa penggunaan $e$-book yang dirancang dalam bentuk modul dengan fungsi dan kelebihannya, dapat membuat siswa tertarik untuk belajar dan meningkatkan kemandiriannya

\section{KESIMPULAN}

Berdasarkan hasil penelitian, maka dapat disimpulkan sebagai berikut :

1. Pengembangan penuntun praktikum dengan menggunakan aplikasi adobe flash pada mata kuliah Kimia Organik 1 ini meliputi tahap-tahap sebagai berikut yaitu ;1) analisis potensi dan masalah, 2) mengumpulkan data, 3) desain produk, 4) validasi desain, 5) revisi desain, 6) uji coba produk, 7) revisi produk.

2. Respon mahasiswa terhadap penuntun praktikum dengan menggunakan aplikasi adobe flash pada mata kuliah Kimia Organik 1 sangat baik. Pada uji coba keterbacaan penuntun yang dikembangkan diperoleh sebesar 4,204 (kategori sangat menarik dan respon mahasiswa sebesar 3,936 (menarik). Penuntun praktikum kimia organik 1 menggunakan program Adobe Flash memiliki tampilan dan desain yang bagus dan menarik karena mahasiswa bisa langsung mengakses penuntun praktikum menggunakan smartphone/ laptop, serta langsung mengisi hasil pengamatan dan pembahasan di laptop. Di dalamnya juga terdapat video serta materi yang disajikan secara virtual sehingga memotivasi mahasiswa untuk melakukan praktikum. Berdasarkan hasil validasi ahli dan uji coba ke mahasiswa, pengembangan penuntun praktikum kimia organik 1 ini layak untuk diterapkan dalam kegiatan pembelajaran di kelas.

\section{DAFTAR PUSTAKA}

Alperi M, Handayani D. (2018). Quality Mapping Analysis of Methods, Media and Learning Resources Usage at Junior High School. 1st International Conference on Educational Sciences and Teacher Profession (ICETeP 2018) Advances in Social Science, Education and Humanities Research pp: 323-328.

Alperi, M. (2019). Peran Bahan Ajar Digital Sigil Dalam Mempersiapkan Kemandirian Belajar Peserta Didik. Jurnal Teknodik Vol. 23 No. 2, Desember 2019. DOI: Http://Dx.Doi.Org/10.32550/Teknodik. Hal.99-110.

Arifah, Isnaeni, (2014), Pengembangan Buku Petunjuk Praktikum Berbasis Guided Inquiry Untuk Mengoptimalkan Hands On Mahasiswa Semester II Program Studi Pendidikan Fisika Universitas Muhammadiyah Purworejo Tahun Akademik 2013/2014. Radiasi, Jurnal Berkala Pendidikan Fisika. 5(1) : 24-28 
Ditama, Viandhika, (2015), Pengembangan Multimedia Interaktif Dengan Menggunakan Program Adobe Flash Untuk Pembelajaran Kimia Materi Hidrolisis Garam SMA Kelas XI, Jurnal Pendidikan Kimia (JPK), 4(2) : 23-31

Guntari, Desi Destiani. (2012). Penerapan Penuntun Praktikum Kimia Skala Kecil Dalam Ranah Psikomotor Pada Subtopik Pembuatan Indikator Asam Basa Alami. Universitas Pendidikan Indonesia. repository.upi.edu

Handayani D, Sundaryono A and Rohiat S 2018 Think Pair Share Cooperative Learning Model Using Edmodo Application. 3rd Asian Education Symposium (AES 2018) Advances in Social Science, Education and Humanities Research pp 253-258

Merdekawati, Agustin Dwi Cahya, (2014), Pengembangan One Stop Learning Multimedia Menggunakan Software Adobe Flash Pada Materi Bentuk Molekul Dan Gaya Antar Molekul Kelas XI SMA, Jurnal Pendidikan Kimia (JPK), 3(1) : 95103.
Septiana, Nurul, )2016), Pengembangan Buku Petunjuk Praktikum Berbasis Green Chemistry untuk SMA/MA Kelas XI Semester 2, Edu Sains,: Jurnal Pendidikan Sains. 4(2) : 115-121

Stone, R., (2013). Cara-cara Terbaik Untuk Mengajar Sains Yang Dilakukan Oleh Guru-guru Peraih Penghargaan, PT Indeks, Jakarta

Sugiyono, (2012), Metode Penelitian Kuantitaif Kualitatif dan $R \& B$, Alfabeta, Bandung

Sugiyono, (2017), Metode Penelitian Kuantitatif Kualitatif dan $R \& D$, Alfabeta, Bandung

Tawil, M dan Liliasari, (2014), Keterampilanketerampilan Sains dan Implementasinya dalam Pembelajaran IPA, Badan Penerbit UNM, Makasar

Wihardjo, Edi, (2007), Pembelajaran Berbantuan Komputer, Universitas Jember, Jember 